\title{
REKONSTRUKSI MAKNA TOLERANSI
}

\author{
Imam Hanafi \\ Institute for Southeast Asian Islamic Studies (ISAIS) \\ imam_hanafi@uin-suska.ac.id.
}

\begin{abstract}
Abstrak
Tulisan ini mendiskusikan tentang pentingnya pemahaman bahwa pluralitas atau keragaman itu merupakan sebuab keniscayaan yang tidak terbantabkan. Oleh karena itu, diperlukan sikap tasamuh atau toleransi agar bisa saling memahami dan menghormati antar sesama manusia yang berbeda antara satu dengan yang lainnya. Toleransi yang dimaksud dalam tulisan ini adalah toleransi yang tidak hanya bersifat recognize atau pengakuan semata, melainkan dalam bentuk nilai implementatif. Artinya, toleransi harus menjadi nilai keseharian bagi umat Islam dalam menyikapi setiap perbedaan yang muncul di masyarakat.
\end{abstract}

Kata kunci: Toleransi, perbedaan, dan nilai

\section{Pendahuluan}

Indonesia, sebagai negara multikultural, telah mengalami berbagai kekerasan, yang melibatkan perbedaan pemahaman ke-Tuhanan atau keagamaan. Hal ini disebabkan oleh adanya simbol-simbol agama sebagai justifikasi atas aksi-aksi yang dilakukan (legitimation of violence acts).

Fakta ini dapat dilihat, antara lain; Plaza Hayam Wuruk (15/4/1999), Masjid Istiqlal (19/4/1999), Kejaksaan Agung (4/6/2000), Kedubes Filipina Jakarta (3/8/2000), Bursa Efek Jakarta (13/9/2000), serangkaian bom natal di Jakarta, Bekasi, Sukabumi, Mataram, Pematangsiantar, Medan, Batam dan Pekanbaru (24/12/2000), Gereja Santa Anna dan Huria Kristen Batak Protestan (HKBP) Jakarta (22/7/2001), Gereja Bethel Tabernakel Kristus Alfa Omega Semarang (31/7/2001), Plaza Atrium
Jakarta (23/9/2001), Australian International School (AIS) Jakarta (6/11/2001), Restoran KFC Makassar (12/10/2001) (Bambang Abimanyu, 2006: 83-90; Tempo, April 2011: 32).

Beberapa kasus di atas, jika dirunut kepersoalan teologis, maka ia mempunyai akar sangat kuat terhadap adanya perbedaan pemahaman (baca; keyakinan) ke-Tuhanan.

Hal ini, tentu mengancam keselamatan publik, karena telah masuk pada kejahatan terhadap nilai-nilai kemanusiaan (crime against bumanity) dan kejahatan luar biasa (extra ordinary crime).

Pada posisi ini, agama sepertinya tidak lagi menjadi sebuah kesatuan entitas (entities integrity), kekuatan pendorong (driving force) bagi terciptanya sebuah tatanan yang rahmatan lil alamin. Agama juga bukan lagi sebuah entitas 
yang mampu memberikan kedamaian, kesejukan, dan keramahan bagi terciptanya keharmonisan sosial beragama (Rubaidi, 2005: 14-15).

Lebih-lebih, salah satu bagian penting dari konsekuensi tata kehidupan global yang ditandai kemajemukan etnis, budaya, dan agama tersebut, adalah membangun dan menumbuhkan kembali semangat ber-tasâmuh dalam masyarakat. Karena pada hakikatnya kita semua adalah sebagai seorang "saudara" dan "sahabat". Bahkan, Islam melalui AlQur'an dan Hadistnya juga mengajarkan sikap-sikap toleran. Dalam kaitannya yang langsung dengan prinsip inilah Allah, di dalam Al-Qur'an surat Yunus ayat 99, menegur keras Nabi Muhammad SAW ketika beliau menunjukkan keinginan dan kesediaan yang menggebu untuk memaksa manusia menerima dan mengikuti ajaran yang disampaikanya, sebagai berikut:

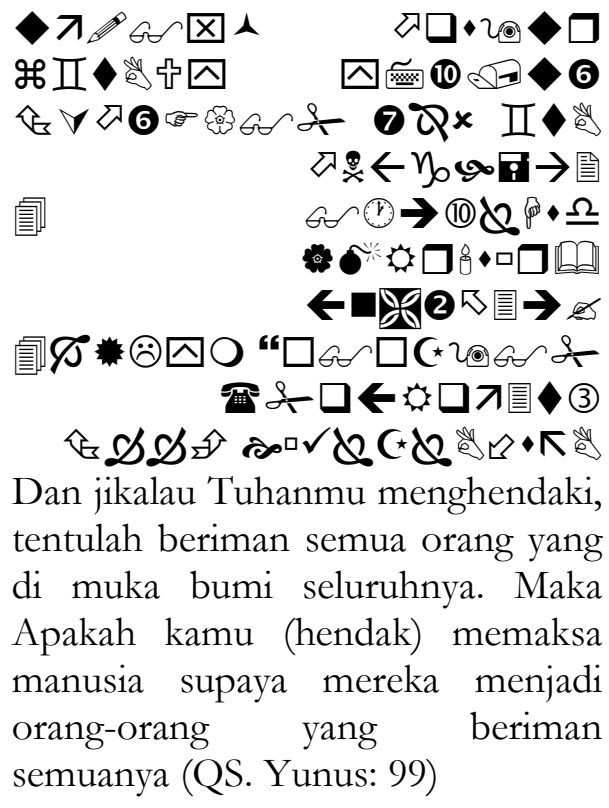

Ayat di atas telah mengisyaratkan bahwa manusia diberi kebebasan percaya atau tidak. Kaum Nabi Yunus yang tadinya enggan beriman, dengan kasih sayang Allah swt. yang telah memberi peringatan kepada mereka, hingga kaum Yunus yang tadinya membangkang, kemudian atas kehendak mereka sendiri mereka sadar dan beriman. Demikianlah prinsip dasar Al-Qur an yang berkaitan dengan masalah pluralisme dan toleransi. Karena Islam menilai bahwa syarat untuk membuat keharmonisan adalah pengakuan terhadap komponenkomponen yang secara alamiah berbeda.

\section{Argumentasi Keragaman Menjaga Toleransi}

Manusia secara filosofis merupakan makhluq bomo religious, yakni meniscayakan agama sebagai sesuatu yang given, niscaya, dan kebutuhan mendasar setiap manusia. Manusia secara eksistensial memiliki kecenderungan ganda; jasmaniah dan rohaniah, fisikalempiris dan supra-empiris, dunia dan akbirat (Ahmad Barizi, 45). Keberadaan sebuah agama diyakini dapat memiliki kemampuan untuk "memfasilitasi" aspirasi, inspirasi, dan harapan-harapan yang tidak mampu dijangkau oleh kemampuan manusia.

Ketika agama lahir dan turun, maka ia tidak lepas dari konteks ruang dan waktu, sekaligus sangat terkait dengan kualitas individu dan mayarakat dalam memahami setiap pesan yang 
diajarkan setiap agama. Setiap orang atau masyarakat tertentu akan menggunakan simbol-simbol tertentu dalam mengekspresikan nilai keagamaan tersebut. Karena setiap individu dan kelompok masyarakat, mempunyai kultur yang beragam, maka ekspresi sebuah agama pun secara cultural dan simbolik, akan beragam pula. Contoh yang sangat sederhana adalah perbedaan bahasa. Sehingga meskipun pesan Keesaan Tuhan pada substansinya sama, tetapi formula bahasanya berbeda.

Setiap bentuk kepercayaan ini, memuat nilai-nilai yang mengharuskan manusia untuk menerjemahkan "firmanNya" kedalam tradisi yang mengitarinya. Proses penerjemahan inilah yang kemudian melahirkan berbagai pandangan dan penafsiran dari "keinginan-Nya" tersebut. Akan tetapi, manusia kebanyakan tidak mampu menangkap kehadiran-Nya. Sehingga, dalam sejarahnya, Tuhan yang diyakini manusia sebagai serba Maha Kuasa itu, tidak diterima secara tunggal, yang pada gilirannya melahirkan cara berkeyakinan yang tidak tunggal (politheisme). Tidak heran jika kemudian, Tuhan ditemukan oleh manusia dalam berbagai bentuk nama dan istilah (Muhammad Wahyuni Nafis, dalam Komaruddin Hidayat dan Ahmad Gaus AF (ed.), 1998: 79-80).

Oleh karena itu, setiap manusia sejatinya mempunyai otoritas yang sama (same outhority) untuk menerjemahkan kepercayaan dan keyakinannya akan
Tuhan, sesuai dengan pengalaman spritual yang dimilikinya. Setiap penafsiran dan penterjemahan ini, kemudian melembaga, menkristal, menjadi sebuah "tata nilai" yang dianggap "paling benar" dibanding penafsiran dan penterjemahan kelompok lain. Intitusionalisasi inilah kemudian disebut sebagai agama.

Persoalannya kemudian adalah "bagaimana menjadikan agama tersebut berfungsi secara positif bagi kehidupan sehari-hari" yang secara eksistensial berhubungan langsung dengan gejalagejala nyata di sekitarnya. Lahirlah berbagai Legenda dan Mitos, sebagai formativisme agama dalam bentuknya yang subjektif.

Ketika manusia hidup dalam lingkaran mitos, maka mitologi agama menjadi cara pandang yang menarik untuk memahami Realitas yang lebih relevan. Oleh sebab itu, cara pandang manusia tersebut perlu - dalam istilah Dawam Rahardjo (dalam Muhammad Wahyuni Nafis (ed.), 1996: 191) "ditelanjangi" melalui penelitian sejarah untuk mencari kebenaran sejarah dari mitos bahkan diapresiasi secara transformatif, dinamis, dan harmonis bagi keberlangsungan keberagamaan manusia (Khalafullah, 1999).

Artinya, mitos mestinya tidak saja menjadi sebuah sistem ilmu dan menjadi orientasi keberagamaan manusia an sich, melainkan menjadikan mitos sebagai 
sistem makna (meaning system) yang secara intelektual merupakan bagian dari pengalaman eksistensialnya dan mempunyai daya sentuh emosional yang kreatif. Hasil kreasi intelektual manusia atas mitos ini, kemudian memunculkan sistem simbol, yaitu suatu kreasi dialektik antara nilai-nilai agama dan budaya yang melingkupinya, dan berfungsi untuk menyederhanakan sesuatu yang kompleks sehingga mudah untuk dipahami.

Eksistensi simbol dalam sistem keyakinan ini, meniscayakan berbagai penafsiran lagi, karena otentisitas dan rasionalitas kebenaran suatu bahasa simbol tersebut, sangat terikat oleh situasi dan kondisi tertentu. Ada dua hal yang patut menjadi cacatan terkait dengan simbol agama ini.

Pertama, seringkali pemeluk sebuah agama terjebak pada penafsiran terhadap sistem simbol tersebut pada sisi harfiahnya. Sementara eksistensi agama pada dasarnya adalah perpaduan antara form dan substance yang tidak bisa dipisahkan. Justru pada makna esensi dari sebuah simbol agamalah, seseorang dapat menembus nilai-nilai universal yang ada dibalik pengungkapan bahasa ritual keagamaan. Dengan kata lain, simbol-simbol dari agama bukanlah tujuan akbir dalam beragama, melainkan sebagai sarana atau media menuju Realitas Tertinggi.
Kedua, sistem simbol dalam beragama mempunyai keberni-laiannya sendiri bagi orang yang mempunyai watak dan sikap mental yang sepadan dengannya. Akan menjadi persoalan, ketika simbolisme agama tersebut kemudian dipaksakan kepada orang yang tidak memiliki watak dan sikap sama dengan simbol agama yang dimaksud.

Dalam al-Qur'an, proses penemuan "Sesuatu yang Maha Kuasa" yang kemudian dimaknai dengan seperangkat simbol yang menyertainya, dihadirkan dengan nama Allah. Selain itu, terdapat nama-nama lain yang disebutkan dalam al-Qur'an (QS. al-Isra: 110), dengan sebutan al-Asma al-Husna (Nama-Nama yang Indah). Sebagian besar Ulama sepakat bahwa "NamaNama yang Indah" ini sebanyak 99 nama. Namun sebenarnya nama-nama Allah tersebut tidak terbatas pada sejumlah itu (al-Ghazali, 1996: 205-208).

Nama Allah itu sendiri seringkali disebut dengan ism al-Jalalah atau ism alJam', yaitu nama yang mencakup atau mewadahi semua nama Tuhan yang lain (untuk lebih jelas lihat Komaruddin Hidayat dan Muhammad Wahyuni Nafis, 1995: 23-48). Karena itu, kata Allah mengacu pada Tuhan yang absolut, suatu Dzat Yang Maha Akbar dan Ghaib, yang hakikat kualitasnya tidak mungkin lagi dideskripsikan dan ditangkap oleh daya nalar manusia. 
Istilah "Allah" itu sendiri sudah dikenal oleh masyarakat Arab Pra-Islam. Akan tetapi menurut Winner, sebagaimana yang dikutip oleh al-Faruqi, istilah Allah bagi mereka dikenal sebagai dewa yang mengairi bumi, sehingga mampu memberikan kesuburan bagi pertanian dan tumbuh-tumbuhan serta memberi minum ternak-ternak mereka (Ismail Raji al-Faruqi and Lois Lamya alFaruqi, 1986: 65). Ketika Islam datang, istilah Allah ini dirubah dan dipahami sebagai Tuhan yang Maha Esa, tempat berlindung bagi segala yang ada, tidak beranak dan tidak diperanakkan. Juga tidak ada satupun yang menyerupai-Nya (QS. al-Ikhlash: 1-4).

Menurut Ibn Arabi, Allah sebagai Dzat yang Absolut dan Maha Ghaib tidak memerlukan nama. Dan jikalau yang Absolut itu diberi nama, maka nama-nama itu tidaklah ada yang tepat, demikian kata Lao-Tzu (Muhammad Wahyuni Nafis (ed.), 1996: 85). Hal ini wajar, karena definisi itu memberikan penciutan dan penyempitan dari sebuah realitas (Komaruddin Hidayat dan Muhammad Wahyuni Nafis, 1995: 33). Maka, ketika Allah yang Absolut didefinisikan, maka Ia tidak lagi menjadi Absolut.

Oleh karena itu, pluralitas atas nama-nama Tuhan dalam bentangan sejarah panjang manusia harus dipahami menjadi sebuah kemestian. Akan tetapi, bahwa semua nama itu hanya dapat dijadikan jastifikasi bagi nama dan sifat, tidak dalam pengertian esensi. Dalam ungkapan Raimundo Pannikar (1979: 266), perjalanan tersebut disebut sebagai the dialectic of the name of God. Selanjutnya Raimundo Pannikar, merumuskan sembilan kategori dialektika yang disebut dengan kairological moment, lima di antaranya adalah;

Pertama, jauh sebelum adanya sistem keberagamaan yang mengajarkan ke-Esaan Tuhan, setiap Tuhan dipahami sebagai tuhan yang lokal, dengan berbagai namanya yang lokal pula. Artinya, mengetahui Tuhan berarti mengetahui nama-Nya, sebaliknya tidak mengetahui nama-Nya berarti tidak mengetahui Tuhan.

Kedua, pengertian pluralitas Tuhan tersebut, mesti dipahami sebagai nama. Karena setiap nama Tuhan, meskipun menunjuk pada satu Tuhan, tetapi tidak dalam pengertian politheisme.

Ketiga, pluralitas nama Tuhan hanya bisa dipahami sebagai manifestasinya. Sehingga setiap nama Tuhan tidak membuat lemah sifat ketuhanannya, karena semua nama itu merujuk pada sifat tuhan.

Keempat, pluralitas nama-nama Tuhan tersebut, bukanlah nama Tuhan dalam pengertian yang sebenarnya. Karena nama Tuhan yang sebenarnya justru berada atau tersembunyi dan rahasia.

Kelima, esensi dari nama rahasia Tuhan itu tidak bisa ditangkap oleh 
manusia, akan tetapi karena manusia mampu menangkap dan menyaksikan sesuatu tanda kekuatan Tuhan pada yang tampak, maka muncul kesadaran untuk mengetahui-Nya. Lebih jauh, Pannikar (1979: 267) menulis :

Each name of God does not exchaust the divinity, since there are other names that also refer to the divinity. The essence of the secret name is that it us unknown. God is the question about him, to find him means to seek him; to know him means not to know him (to name him means to invoke bim as an unknown God with an unknown name), for his name is the question, pure, and simple. God is not subtance and has no name, but he is a question, a simple pronoun, an interrogative: Who?

Mengenai Tuhan ini, secara filosofis telah diungkapkan dalam alQur'an dengan menyebutnya Huwa (Dia), yang kemudian disebut dengan Allah atau nama-nama yang indah (alasma al-husna) lainnya. Dalam salah satu firman-Nya, Allah mengatakan dalam alQur'an, “Katakanlah (ya Muhammad), Huwa (Dia) yaitu (yang kamu dan orangorang Arab biasa menyebutnya) Allah itu, adalah Maha Esa, Tempat Bergantung (bagi segala yang ada). Dia tidak beranak dan tidak diperanakean. Dan tidak ada satupun yang menyerupai-Nya (QS. al-Ikhlas: 1-4).

\section{Penjelasan tentang perjalanan} pemikiran manusia tentang Tuhan diatas, menunjukkan bahwa Tuhan bagi manusia merupakan suatu hal yang sangat manusiawi dan alami. Pemahamanan manusia akan Tuhan muncul dari kesadaran diri manusia bahwa pada dasarnya manusia sangat lemah, lebih-lebih ketika dihadapkan pada berbagai peristiwa alam yang tidak dijangkaunya.

Oleh karenanya, Tuhan dipahami dengan berbagai "sosok" yang beragam. Ada yang meyakini-Nya sebagai yang memberi Azab, ada yang mengimaniNya sebagai yang memberi rahmat dan kebaikan, dan ada pula yang meyakiniNya sebagai yang mengendalikan peristiwa alam, dan seterusnya.

Pemahaman akan eksistensi Tuhan ini, berimplikasi pada perilaku sosial bagi yang meyakini dan mengimani-Nya, dengan tingkat pemikiran yang berbedabeda. Tuhan-nya orang-orang sufi tentu berbeda denga Tuhan yang dipahami oleh kaum filosuf. Begitu juga ketika Tuhan dipahami oleh seorang Teolog, Mufassir, dan Mufaqqih. Belum lagi ketika kaum Saintis, yang memiliki metodologi yang berbeda, sudah pasti memiliki pemahaman yang berbeda pula dalam memandang Tuhan.

Bahkan satu Sufi dengan Sufi lainnya, ketika mengungkapkan atau berbicara tentang Tuhan memiliki perbedaan. Hal ini, semakin menandaskan bahwa pluralitas dalam memahami dan meyakini Tuhan itu pasti menjadi sebuah keniscayaan, karena ia benar-benar merupakan realitas yang tidak bisa dielakkan. 
Al-Qur'an dan hadits sendiri sebagai sebuah teks yang mengandung berbagai pesan, ajaran, dan amanat, dimaknai dan aktualisasikan oleh umat Islam secara berbeda-beda. Realitas dari kemajmukan penafsiran ini, menurut Munzir Hitami merupakan sebuah tuntutan bagi umat Islam untuk bersikap moderat. Lebih jauh Munzir Hitami (2005: 220-221) mengatakan;

Pluralitas pemahaman ajaran agama dan kitab suci seperti al-Qur'an adalah sebuah realitas yang tidak dapat dipungkiri. Hal tersebut terjadi karena dalam Islam sendiri memang tidak ada lembaga yang mempunyai otoritas untuk menyatukan pemahaman terhadap al-Qur'an sebagaimana yang terdapat dikalangan Nasrani pada umumnya, dimana Gereja menjadi satu-satunya lembaga yang memegang otoritas untuk menafsirkan kitab sucinya. Meskipun demikian, hal itu tidak berarti pluralitas penafsiran dikalangan mereka tidak ada. Disini kesadaran akan Kemajmukan perlu ditumbuhkan.

Umpamanya, kesadaran yang menyatakan bahwa realitas pluralitas dari sudut agama bukanlah suatu kebetulan, karena tak ada satupun entitas didalam ala mini yang monolitik sifatnya. Semuanya beragam, termasuk agama. Dengan demikian, klaim monolitik, termasuk dalam konteks agama, sekurangkurangnya dari keniscayaan pengalaman nyata, layak untuk dipertanyakan.

Oleh sebab itu, munculnya keragaman pandangan dalam mengekspresikan setiap pesan, amanat, dan ajaran Tuhan merupakan sebuah keniscayaan. Karena bagaimana mungkin seseorang mampu memahami pesan, amanat, dan ajaran Tuhan tersebut sebagaimana yang tertuang dalam teksteks agama dengan benar sesuai dengan keinginan Tuhan, sementara ia sendiri tidak mampu berhadapan langsung dengan-Nya?

Sehingga dalam menyikapi artikulasi keberagamaan tersebut, para ulama biasanya bersikap tawadhu', yaitu dengan mengakhiri hasil interpretasinya dengan ungkapan wallabu a'lam bi alshawab. Karena memang pada hakikatnya, hanya Allah-lah yang tahu dengan apa yang dikehendaki-Nya.

\section{Rekonstruksi Teologis; Menegaskan makna Toleransi}

Adanya berbagai ragam agama yang disertai dengan aneka kitab suci yang dimilikinya, merupakan bukti empiris adanya pluralitas agama. Pluralitas agama ini kemudian terejawantah menjadi realitas sosial yang menyejarah dalam kehidupan umat manusia. Karena itu, secara historis dikenal banyak umat agama dan kepercayaan seperti: Sabi'ah, Yahudi, Nasrani, Islam, Budha, Hindu, Konghucu, Sinto, dan lainnya.

Eksistensi pluralitas agama sebagai sebuah realitas sosial dengan demikian menjadi nalar baku yang harus diterima oleh setiap umat agama manapun. Menolak nalar baku berarti menolak 
realitas dan ini berarti lari dari kenyataan hidup, lari dari ayat-ayat kauniyah yang diberikan oleh Tuhan, Sang Pencipta pluralitas itu sendiri. Juga berarti menegasikan eksistensi kemanusiaannya sendiri, yakni sebagai makhluk individu sekaligus makhluk sosial.

Karena itu, bagi umat agama manapun, pluralitas agama harus dilihat dalam dua aspek sekaligus; realitas teologis dan realitas sosiologis. Realitas teologis maupun realitas sosiologis harus diinsafi sebagai konsekuensi logis dari pluralitas agama itu sendiri. Sebab, biasanya dalam sejarah umat manusia, bahkan dalam Islam sendiri, masingmasing individu mempunyai konsepsi subyektif tentang realitas Tuhannya, dan pada gilirannya konsepsi tersebut dianggap sebagai pemahaman yang “obyektif”.

Disinilah kemudian komunalitas sebuah agama kehilangan deep insight, "hati nurani" kemanusiaan yang paling dalam. Pada aras ini, keberadaan agama biasanya menjadi variabel penyebab munculnya beragam rintangan komunikasi antar sesama umat manusia dalam melakukan interaksi sosial. Kenyataan di lapangan memperkuat asumsi ini, seperti kasus kekerasan yang menimpa Islam Ahmadiyah dan Aliansi Kebangsaan untuk Kebebasan Beragama dan Berkeyakinan yang masih hangat dalam ingatan kita, kasus Ketapang, Kupang, Ambon, dan daerah lain di Indonesia serta kasus kekerasan yang menimpa suku Uighur, Xinjiang, China, beberapa tahun yang lalu.

Ketidakmampuan umat beragama mengakui kedua realitas tersebut mendorong pelembagaan dan pembudayaan sikap serta perilaku individual dan sosial untuk melakukan pembenaran terhadap kepentingan keyakinan keagamaannya sendiri tanpa mempedulikan kepentingan umat agama lain. Akibatnya terbentuk sikap individual dan sosial yang tidak siap menerima kehadiran umat dan agama lain yang bukan termasuk kelompok dan agamanya.

Sikap seperti ini akan merusak pranata sosial, politik, serta merobekrobek pluralitas, yang bila dicermati secara mendalam akan melahirkan sikap toleransi terhadap sesama umat beragama. Bila kesadaran akan pluralitas agama naik, maka naik pula sikap toleransi yang dimiliki umat beragama. Demikian juga sebaliknya, bila kesadaran akan pluralitas agama turun, maka turunlah sikap toleransi tersebut.

Kurangnya sikap toleransi terhadap sesama umat beragama akibat melemahnya kesadaran akan pluralitas agama ini menjadi pemicu banyaknya konflik agama di berbagai belahan dunia termasuk Indonesia. Hal ini memperkuat asumsi bahwa sikap toleransi dan relegiusitas bangsa ini sesungguhnya baru berada pada kulit luarnya saja belum menyentuh kesadaran 
terdalamnya. Andai telah menyentuh kesadaran terdalamnya tentu tidak akan terjadi konflik di negeri ini. Negeri yang beragam agama dan realitas sosialnya.

Secara normative, toleransi merupakan salah satu diantara sekian ajaran inti dari Islam. Toleransi sejajar dengan ajaran fundamental yang lain, seperti kasih sayang (rahmab), kebijaksanaan (bikmab), kemaslahatan universal (al-maslabah al-ammab), dan keadilan (Syarbini, dkk, 2011:20-21).

Makna ini selanjutnya berkembang menjadi sikap lapang dada/ terbuka (welcome) dalam menghadapi perbedaan yang bersumber dari kepribadian yang mulia (Al-Munawar, 2007)

Dengan demikian, berbeda dengan kata tolerance yang mengandung nuansa keterpaksaan, maka kata tasamuh memiliki keutamaan, karena melambangkan sikap yang bersumber pada kemuliaan diri (al-jud wa al-karam) dan keikhlasan.

Jika dicermati dengan seksama, pemahaman tentang toleransi tidak dapat berdiri sendiri. Ia terkait erat dengan suatu realitas lain di alam yang merupakan penyebab langsung dari lahirnya toleransi. Memahami toleransi an sich tidak akan ada artinya tanpa memahami realitas lain tersebut, yaitu kemajemukan

$\begin{array}{ccc}\text { W.J.S } & \text { Poerwadarminto } & (1986) \\ \text { menyatakan } & \text { toleransi } & \text { adalah } \\ \text { sikap atau } & \text { sifat menenggang } & \text { berupa }\end{array}$

menghargai serta membolehkan suatu pendirian, pendapat, pandangan, kepercayaan maupun yang lainnya yang berbeda dengan pendirian sendiri.

Toleransi juga berarti sikap menghargai, menerima, dan menghormati perbedaan yang terjadi di masyarakat sebagai takdir Tuhan yang secara sengaja diciptakan untuk manusia, agar bisa saling mengenal satu sama lain. Hal ini dapat dipelajari dari frman Allah pada surat Yunus : 99, al-Kahf : 29, alBaqarah : 256, dan beberapa ayat-ayat Al Qur'an lainnya.

Selain ajaran tekstual yang tertuang di daam al-Qur'an, Nabi Muhamad SAW, sebagai tauladan bagi umat Islam, juga memberikan contoh kongkret bagaimana beliau menerima dan menghormati delegasi agama lain (baca; Kristen) di masjid. Bahkan, yang lebih mencengangkan, beliau mempersilahkan pemeluk orang Kristen tersebut untuk melakukan kebaktian (peribadatan) di masjid.

Selain itu, al-Qur'an pun melegitimasi bahwa persoalan agama adalah persoalan individu yang tidak bisa dipaksakan. Agama, berdasarkan alQur'an QS; Al Qashah: 55, disebut sebagai hak mutlak yang dimiliki Allah SWT, Nabi Muhammad, sebagai utusanNya, tidak memiliki hak apapun untuk 'mengislamkan' orang lain, termasuk pamannya sendiri. 
Menjadi toleran adalah membiarkan atau membolehkan orang lain menjadi diri mereka sendiri, menghargai orang lain, dengan menghargai asal-usul dan latar belakang mereka. Toleransi mengundang dialog untuk mengkomunikasikan adanya saling pengakuan.

Inilah gambaran toleransi dalam bentuknya yang solid. Toleransi bisa bermakna penerimaan kebebasan beragama dan perlindungan undangundang bagi hak asasi manusia dan warga negara. Toleransi adalah sesuatu yang mustahil untuk dipikirkan dari segi kejiwaan dan intelektual dalam hegemoni sistem-sistem teologi yang saling bersikap ekslusif (Baidhawi,2002).

Jika pengertian ini diimplementasikan dalam kehidupan beragama, maka dapat berarti mengakui, menghormati dan membiarkan agama atau kepercayaan orang lain untuk hidup dan berkembang.

Adapun sebagai prinsip metodologis, toleransi adalah tidak hanya sekedar pengakuan (recognize), melainkan totalitas penerimaan terhadap realitas pluralitas itu sendiri.

Model recognize ini menurut Richard H. Dees (1999) bahwa model toleransi seperti ini masih berada pada tataran modus vivendi, toleransi masih berada pada pengakuan tertulis saja. Kelemahan model toleransi ini adalah kuatnya peran politik dalam menyikapi toleransi. Sehingga toleransi sangat mudah untuk "dikoyak-koyak".

Dengan demikian, yang dimaksud konsep toleransi di sini adalah suatu sikap saling mengerti, memahami, dan menghormati adanya perbedaanperbedaan demi tercapainya kerukunan antar umat beragama. Dan dalam berinteraksi dengan aneka ragam agama tersebut, diharapkan masih memiliki komitmen yang kokoh terhadap agama masing-masing.

Toleransi dengan demikian, tidak hanya berhenti pada tataran wacana. Ia harus diturunkan menjadi aktivitas dan nilai yang hidup (living values) dalam kehidupan nyata. Manusia yang beriman akan konsisten antara sikap dan perilakunya (Wahid, 2001). Begitu juga dalam bersikap toleran, keberimanan adalah konsistensi antara keyakinan dan sikap.

Implementasi toleransi mencakup seluruh dimensi kehidupan, mulai dimensi spiritual, moral, ideologi hingga politik. Khazanah keislaman sesungguhnya sangat kaya terhadap perspektif toleransi. Etika perbedaan pendapat dalam Islam, misalnya, menyatakan bahwa tidak boleh ada pemaksaan dalam bentuk apa pun kepada orang lain.

Toleransi juga menghendaki adanya self esteem, yaitu bagaimana mempersepsi diri dan orang lain. Perspektif positif terhadap diri sendiri 
dan orang lain akan menghasilkan toleransi yang baik, sementara perspektif negatif akan menghasilkan intoleransi. Implikasi perspektif ini adalah toleransi bisa tumbuh dan berkembang secara baik pada orang yang telah memahami realitas kemajemukan secara positif. Hal ini sejalan dengan konsep toleransi yang mengandaikan nilai bersama sehingga agama-agama yang berbeda dapat hidup berdampingan dengan damai (Baidhawy, 2002).

Lebih jauh lagi bahwa toleransi akan melahirkan munculnya kemampuan untuk berempati dan membangun keasadaran kemanusiaan dalam skala yang lebih luas. Tumbuhnya toleransi bisa membuka belenggu kebodohan dan kemiskinan (Wahid, 2007).

Hal ini disebabkan karena toleransi dalam maknanya yang substansial bukan sekadar sikap pasif, tetapi juga sikap kritis-apresiatif. Sikap semacam ini mendorong tumbuhnya berbagai tindakan transformasional dalam kerangka membentuk kehidupan yang lebih baik.

Ada beberapa prinsip toleransi yang dapat ditelusuri dalam al-Qur'ân, yaitu diawali dengan pengakuan adanya pluralitas, lalu mengarah pada nilai, yaitu berlomba dalam kebajikan, interaksi dalam beragama, serta keadilan dan persamaan dalam perlakuan. Menjaga hubungan baik dan kerjasama antar umat beragama yang terdiri dari menjaga hubungan baik antar sesama umat beragama, dan kerjasama antar sesama umat beragama. Salah satu ayat yang dijadikan dasar untuk bersikap tasamuh ini adalah :

"Hai manusia, sesungguhnya Kami menciptakan kamu dari seorang laki-laki dan seorang perempuan dan menjadikan kamu berbangsa-bangsa dan bersuku-suku supaya kamu saling kenal-mengenal. Sesungguhnya orang yang paling mulia diantara kamu disisi Allah ialah orang yang paling taqwa diantara kamu. Sesungguhnya Allah Maha Mengetahui lagi Maha Mengenal." (Q.S Al-Hujurat : 13)

Diriwayatkan oleh Abû Dâwûd bahwa Q.S al-Hujurat ayat 13 ini turun berkenaan dengan Abû Hind yang pekerjaan sehari-harinya adalah pembekam. Nabi meminta agar Bani Bayadhah agar menikahkan salah seorang puteri mereka dengan Abû Hind, tetapi mereka enggan dengan alasan tidak wajar mereka menikahkan puteri mereka dengannya yang merupakan salah seorang bekas budak mereka. Sikap keliru ini dikecam oleh alQur'ân dengan menegaskan bahwa kemuliaan di si Allah bukan karena keturunan atau garis kebangsawanan tetapi karena ketaqwaan. (Shihab, 2004),

Dan Kami telah menurunkan alQur'ân kepadamu dengan membawa kebenaran, mengkonfirmasi dan menjadi batu ujian terhadap kitabkitab yang ada sebelumnya; maka putuskan perkara mereka menurut apa yang diturunkan Allah dan janganlah engkau mengikuti hawa nafsu mereka dengan mengikuti 
hawa nafsu mereka dengan meninggalkan kebenaran yang telah datang kepadamu. Untuk masingmasing dari kamu (umat manusia) telah Kami tetapkan hukum (syariah) dan jalan hidup (minhaj). Jika Allah menghendaki, maka tentulah Ia jadikan kamu sekalian umat yang tunggal (monolitik). Namun Ia hendak menguji kamu sekalian berkenaan hal-hal yang telah dikaruniakan-Nya kepada kamu. Maka berlombalah kamu sekalian untuk berbuat kebajikan. Kepada Allah-lah tempat kalian semua kembali, maka Ia akan menjelaskan kepadamu sekalian tentang perkara yang pernah kamu perselisihkan." (Q.S Al-Maidah : 48)

Ayat ini, menurut Alwi Shihab (2004), dengan jelas menganjurkan suatu interaksi ko-eksistensi yang konstruktif dan penuh kedamaian, atau bahkan ayat ini mendesak kita untuk dengan segera menciptakan suatu masyarakat global yang terintegrasi.

Selanjutnya, didalam al-Qur'ân diyatakan bahwa pluralitas adalah salah satu kenyataan objektif komunitas umat manusia, sejenis hukum Allah atau sunnah Allah, dan bahwa hanya Allah yang tahu dan dapat menjelaskan, di hari akhir nanti, mengapa manusia berbeda satu dari yang lain. Muhammad Asad, sebagaimana dikutip oleh Nurcholish Madjid (1998), salah seorang penafsir AlQur'ân dalam tafsirnya atas ayat di atas menyatakan:

"Pernyataan "masing-masing dari kamu" di atas menunjuk kepada berbagai komunitas yang membentuk umat manusia secara keseluruhan. Kata syir'ah (atau syari'ah) secara harfiah berarti "jalan menuju kepada sumber air" (dari mana manusia dan binatang memperoleh unsur yang tidak dapat dipisahkan dari hidup mereka), dan dalam Al-Qur'ân digunakan untuk menunjuk ke sistem hukum yang harus ada untuk mencapai kebaikan sosial dan spiritual sebuah komunitas. Kata minhâj, pada sisi lain menunjuk kepada "jalan yang terbuka", khususnya kata dalam pengertian abstrak: yakni, jalan hidup.

Toleransi tidak akan terbangun dengan baik, jika cara pandang kita atas mereka yang berbeda, dengan cara pandang negative, penuh curiga. Cara pandang itu pasti akan berpengaruh pada perilaku. Maka semakin tinggi kecurigaan dan negative cara pandang kita, justru akan memperkuat potensi konflik, dan ajaran kita menjadi sangat eksklusiv, yang menurut Abdurrahman Wahid (2001) kerusuhan di berbagai tempat di Indonesia disebabkan-salah satunyaoleh pemahaman keagamaan yang eksklusif ini.

Karena itulah maka pengembangan paradigma positif sangat penting artinya. Pada perspektif inilah, toleransi menemukan titik signifikansinya. Relasi dengan umat yang berbeda agama harus dilandasi oleh sikap yang tulus dan ikhlas (Wahid, 1981).

Dalam pandangan Zuhairi Misrawi menggaris bawahi beberapa hal penting 
lain di dalam implementasi sikap toleran di masyarakat, yaitu; mengakui perbedaan dan keragaman. Dalam konteks agama-agama dan paham keagamaan, mengakui keragaman shari'ah sebagai jalan menuju Tuhan, dan mengakui potensi keragaman tafsir atau pemahaman keagamaan, merupakan hal yang urgen dalam membangun sikap toleransi antar dan intra umat beragama.

Selanjutnya adalah mencari titik temu dan koeksistensi. Berawal dari nilai-nilai teologis inilah, maka makna toleransi dan upaya menumbuhkan toleransi di dalam masyarakat, tidak dapat dipisahkan dari ajaran subtansial yang dibawa oleh Nabi Muhammad SAW dan anjuran-anjuran penting yang tertera pada teks-teks Qur'ani.

Jika menelisik dari dua konsepsi pendefnisian toleransi, maka sikap toleran hadir sebagai wujud keikhlasan untuk menerima perbedaan, oleh karena perbedaan ini hadir atas nama kehendakNya.

Oleh karena itu, sangat penting agar kiranya ada usaha dan upaya yang bisa dilakukan manusia adalah menjaga alur yang sudah ditentukan ini menjadi kesejukan berbingkai kedamaian, keharmonisan, dan kesetaraan perlakuan di dalam masyarakat. Hal-hal yang menyangkut nilai lain dari sebuah agama, berdasarkan pada anjuran al-Qur'an bisa dikomunikasikan bersama melalui dialog, perdebatan-perdebatan yang sehat (tanpa adanya pemaksaan dan intervensi untuk mengakui

kebenaran satu agama atau keyakinan tertentu), dan mencari aspek-aspek kesamaan universal untuk menjaga kerukunan dan kesejajaran umat beragama di dalam masyarakat.

Islam sendiri tidak pernah diinginkan menjadi agama yang eksklusif, tertutup akan perkembangan dan perubahan zaman, dan komunikasi harmonis dengan agama lainnya. Teksteks Qur'ani dan tauladan Nabi Muhammad pada pembahasan sebelumnya sudah membuktikan bahwa Islam hadir sebagai agama yang penuh dengan kasih sayang serta menjunjung tinggi kemanusiaan.

Dengan demikian, Al-Qur'an dapat dengan mudah mendukung etika perbedaan dan toleransi. AlQur'an tidak hanya mengharapkan, tetapi juga menerima kenyataan perbedaan dan keragaman dalam masyarakat. Hal ini sesuai dengan firman Allah SWT dalam surat al-Hujurat ayat 13 , ayat tersebut menunjukkan adanya ketatanan manusia yang essensial dengan mengabaikan perbedaan perbedaan yang memisahkan antara golongan yang satu dengan golongan yang lain, manusia merupakan tiap keluarga besar.

Di dalam memaknai toleransi ini terdapat dua penafsiran tentang konsep tersebut. Pertama, toleransi negatif yang menyatakan bahwa toleransi itu cukup 
mensyaratkan adanya sikap membiarkan dan tidak menyakiti orang atau kelompok lain baik yang berbeda maupun yang sama.

Kedua, toleransi positif yaitu menyatakan bahwa toleransi tidak hanya sekedar seperti pertama (penafsiran negatif) tetapi harus adanya bantuan dan dukungan terhadap keberadaan orang lain atau kelompok lain.

Toleransi antar umat beragama mempunyai arti sikap lapang dada seseorang untuk menghormati dan membiarkan pemeluk agama untuk melaksanakan ibadah menurut ajaran dan ketentuan agama masing-masing yang diyakini, tanpa ada yang mengganggu atau memaksakan baik dari orang lain maupun dari keluarganya sekalipun. Secara teknis pelaksanaan sikap toleransi antar umat beragamayang dilaksanakan di dalam masyarakat lebih banyak dikaitkan dengan kebebasan dan kemerdekaan menginterpretasikan serta mengekspresikan ajaran agama masingmasing.

\section{Penutup}

Toleransi dan pluralisme sebagai gagasan dan paham keagamaan adalah instrumen penting dalam mewujudkan cita-cita luhur agama Islam sebagai agama yang rahmatan lil alamin.

Semua intelektual Muslim di Indonesia mengakui prinsip toleransi sebagai prinsip yang harus dilindungi atau dijaga dalam masyarakat yang pluralistik. Sikap toleransi merupakan wujud dari prinsip persamaan yang menimbulkan sifat tolong menolong dan sikap kepedulian sosial di antara sesama warga masyarakat, yang pada gilirannya akan melahirkan rasa persatuan dan solidaritas sosial yang kuat dalam kehidupan bermasyarakat.

$$
\text { Menyikapi keberagaman, }
$$
termasuk keberagaman dalam hal keyakinan, Islam menawarkan konsep yang ramah, inklusif dan tidak diskriminatif.

Sebagai bentuk praktis dari pengejawentahan ajaran Islam, fikih telah merumuskan konsep bagaimana seharusnya umat Islam bersikap terhadap pemeluk agama atau komunitas lain. Namun demikian, dalam damai dengan sesama manusia, saling tolong menolong dengan sesama manusia.

Meskipun pada perkembangannya fikih juga pernah berada dalam kondisi dimana rumusan yang ditawarkan bersifat apriori dan cenderung diskriminatif. Persoalan ini kemudian melahirkan gelombang kritis dari para ahli untuk melakukan upaya pembacaan ulang (rethingking) terhadap dogma fikih yang apriori dan diskrimanif serta mengembangkan rumusan fikih yang inklusi-toleran. 


\section{DAFTAR PUSTAKA}

Bagir, Haidar, 2002, "Suatu Pengantar Kepada Filsafat Islam Pasca ibn Rusd" dalam Murtadho Muthahari, Pengantar Pemikiran Shadra ; Filsafat Hikmah, Bandung : Mizan.

Corbin, Henri, 2002. Imajinasi Kreatif Ibn al-Arabi, (tri) Yogyakarta : LKiS.

Chodkewicz, Michel 1999. Konsep Ibn Arabi tentang Kenabian dan Auliya, Jakarta : RajaGrafindo Persada

C. Chitik, William, 2001, The Sufi Path Of Knowledge ; Pengetahuan spiritual Ibn al-Arabi, Yogyakarta : Qalam.

2003, "Ibn 'Arabi dan Mahzabnya" Dalam SH. Nasr (ed) Ensiklopedi Tematis Spritualitas Islam. Bandung : Mizan.

2003, "Rumi dan Tarekat maulaiyyah" Dalam SH. Nasr (ed) Ensiklopedi Tematis Spritualitas Islam. Bandung : Mizan.

Coward, Harold, 1989, Pluralisme dan Tantangan Agama, Yogyakarta : Kanisius

Denny, Frederick M, 2001 "Ritual Islam ; Perspektif dan Teori" dalam Richard M. Martin (ed), Pendekata Kajian Islam Dalam Study Agama. Surakarta : Muhamadiyah University Press.

Daradjat., Zakiyah, 1994. Dasar-Dasar Agama Islam, Jakarta : Bulan Bintang.
Darmawan, Hikayat, 2005, Tuban Tak Sembunyi ; Mencari Agama Untuk Zaman Baru, Bandung : Mizan.

Eaton., Charles Le gai, 2002. "Manusia" dalam Sayyed Hussein Nasr (ed), Ensiklopedia Tematis Spritualitas Islam, Bandung : Mizan

El Fadl, Khaled Abou, 2003. Cita dan Fakta Toleransi Islam ; Puritanisme vs Pluralisme, Bandung : Arasy Mizan

Esack, Farid, 1997, Qur'an Liberation and Pluralism, England, Oneworld,

al-Faruqi, Ismail Raji. 1992. Al-Taubid; Its Implikatians for Though and Life. USA : the International institute of Islamic Thought.

., and Lois Lamya al-Faruqi, 1986, The Cultural Atlas of Islam, New York : MacMilan Publisher Company

Gibb, HAR. 1971. (ed), Enclopedia of Islam, vol. III, Leiden : EJ. Briple.

Hadi WM, Abdul, 2001, Tasawuf Yang Tertindas, Kajian Hermeneutik. terhadap Karya-Karya Hamzah Fansur", Jakarta : Paramadina.

Hitami, Munzir, 2005, Menangkap PesanPesan Allah ; Mengenal WajahWajah Hermeneutika Kontemporer, Pekanbaru : Susqa Press.

Hidayat, Komarudin. 1995. "Manusia dan Proses Penyempurnaan Diri" dalam Buddhy Munawar Rahman (ed), Kontekstualisasi Doktrin Islam dalam Sejarah, Jakarta : Paramadina. 
1996. Memahami

Bahasa Agama ; Sebuab kajian Hermeneutik

Jakarta :

Paramadina.

1999, "Melampaui

Nama-Nama Islam dan

Postmodenisme" dalam Edy A.

Efendi (ed), Dekonstruksi Mažbab

Ciputat, Bandung : Zaman

Wacana Mulia.

Hamka, 1980, Tasawnf; Perkembangan dan Pemurniannya. Jakarta : Yayasan Nurul Islam.

1985. Filsafat Ketuhanan, Surabaya : Penerbit Karunia.

1987, Tafsir al-Azhar, Juz I, Jakarta : Panji Mas

Husaini, Moulvi SAQ.. 1931. Ibn Arabi; the Great Muslim Mistic and Thinker, Lahore : Kashmiri.

Ibn al-Arabi, tth. Futubat al-Makizyah. Beirut : Dar al-Fkr.

1988. Misykat al-Anwar (Relung Cahaya), (trj). Jakarta : Pustaka Firdaus

1980. The Bezel of Wisdom. New York : Paulist Press. 1980. 1994. Sufi-Sufi Andalusia

(trj), Bandung : Mizan.

1997. Wasiat-Wasiat Ibn Arabi, (tri), Bandung : Pustaka Hidayah.

2000. Kalimâtullah Kitâb al-Jalâlah, (tri). Surabaya : Pustaka Progresif.
Ibn Taimiyyah, 1990. Kemurnian Taubid, Jakarta : Bumi Aksara

Izutsu, Toshihiko, 1994, Konsep Kepercayaan dalam Teologi Islam ; Analisis Semantik Iman dan Islam, Yogyakarta : Tiara Wacana.

Iqbal, Muhammad, 1982. Membangun Kembali Pikiran Agama dalam Islam (trj), Jakarta : Tinta Mas.

Kamal Hasan., Muhammad. 1989. "Beberapa Dimensi Pendidikan Islam di Asia Tenggara" dalam Taufiq Abdullah dan Shiddique, Tradisi dan Kebangkitan Islam di Asia Tenggara, Jakarta : LP3ES.

Karni, Asrori S. (ed). 2000. Pesan-Pesan Taqwa Nurcholis Madjid. Jakarta: Paramadina.

Kosim, Moch.. 2003. Pluralisme Agama dalam Pendidikan Agama Islam ; Telaah Atas Materi Pendidikan Agama Islam Untuk SMU Kurikulum 1994, Yogyakarta : Fakultas Tarbiyah, IAIN Sunan Kalijaga

Khalafullah, Muhammad Ahmad, 1999, al-Fann al-Qishashiy fi al-Qur'an alKarim, Kairo-Beirut : Sina li alNasyr wa Mu'assasah al-Intisyar al-Araby,

Khan, Inayat, 2002. Kehidupan Spritualitas ; Tiga Esai Klasik tentang Kebidupan Rubani, (trj) Yogyakarta: Pustaka Sufi.

2003. Kesatuan Ideal Agama-Agama (tri), Yogyakarta : Putra Langit. 
1989. Education ; From

Before Birth to Maturuty, USA : Hunter House Inc.

2002. The Heart of Sufisme, (trj), Bandung : Remaja Rosdakarya.

2002. Dimensi Musik dan Bunyi, (tri). Yogyakarta : Pustaka Sufi.

Khan, Pir Vilayat Inayat, 2003, Membangkitkan Kesadaran Spritual; Sebuah Pengalaman Sufistik, Bandung : Pystaka Hidayah.

Khamim., Ahmad. 1987. Beberapa Aspek Epistemologis dalam Pandangan Ibn Arabi,Yogyakarta : IAIN Sunan Kalijaga.

Kartanegara., Mulyadhi 2002. Panorama Filsafat Islam ; Sebuab Refleksi Autobiografi, Bandung : Mizan. 2002

Kuntowijoyo, 1997, Identitas Politik Umat Islam. Bandung : Mizan.

Lubis, Haji Muhammad Bukhari, 1993, The Ocean of Unity, Wabdat alWujud in Persian, Turkish and Malay Poetry, Kuala Lumpur : DBP.

Madjid., Nurcholis. 2000. "Ibn al-Arabi dan Tasawuf" Dalam KuliahKuliah Tasawnf Editor Sukardi, Bandung : Pustaka Hidayah.

. 1995. Islam Agama Kemanusiaan ; Membangun Tradisi dan Visi Baru Islam di Indonesia. Jakarta : Paramadina.
1984. Khazanah

Intelektual Islam, Jakarta : Bulan Bintang

1992. Islam Doktrin dan Peradaban. Jakarta : Paramadina.

1999. Cendekiawan dan Religiusitas masyarakat. Jakarta : Paramadina.

Menuju Tuban. Jakarta :
Paramadina.

1999. "Beberapa Renungan Kehidupan Kegamaan Untuk Generasi Mendatang" dalam Edy A. Effendy, Dekonstruksi Marhab Ciputat, Bandung: Zaman Wacana Mulia.

2000. Perjalanan Religius Umrah dan Haji. Jakarta : Paramadina.

Konsep Kebahagiaan dan Kesengsaraan" dalam Buddhy Munawar Rahman (ed), Kontekstualisasi Doktrin Islam dalam Sejarah, Jakarta : Paramadina. 1998, "Dialog di Antara Ahli Kitab: Sebuah Pengantar" dalam George B Grose \& Benjamin J Hubbaard (ed), Tiga Agama Satu Tuban, Bandung : Mizan.

Marimba., AD.. 1989. Penagantar Filsafat Pendidikan Islam. Bandung : Ma'arif.

Muslim, 1916. al-Shahih ; Kitab al-Iman, no 302, Kairo : Muhammad Ali Shabih. 
Munawir, Ahmad Warson. 1997. Kamus al-Munawir ; Babasa Arab Indonesia. Surabaya : Pustaka Progresif.

Meliono, Anton dkk. 1988. Kamus Besar Bahasa Indonesia, Jakarta : Balai Pustaka

Mudjiono., Imam. 1997. "Peran Pendidikan Islam dalam Mewujudkan Kerukunan Umat Beragama", Dalam Pendidikan Islam Dalam Peradaban Industrial, Yogyakarta : Aditya Media

Mulkhan, Abdul Munir, 2002. Nalar Spritual Pendidikan; Solusi Problem Filosofis Pendidikan Islam, Yogyakarta : Tiara Wacana.

2001. "Pengantar" dalam Jalaluddin Rumi, Kearifan Cinta ; Renungan Sehari-Hari Kutipan Fibi Ma Fibi, (Yogyakarta : Tiara Wacana. , 2005., Satu Tuban Seribu Tafsir, Yogyakarta : Kanisius,

Murata, Sachiko. 2000. The Tao of Islam (trj), Bandung : Mizan.

Noer., Kautsar Azhari. 1996. Ibn al-Arabi ; Wabdatul Wujud dalam Perdebatan, Jakarta : Paramadina.

2002. Tasauf Perennial ; Kearifan Kritis Kaum Sufi. Jakarta : Serambi.

"Menyemarakkan Dialog Agama ; Perspektif Sufi" dalam Edi A. Efendi, DekonstruksiMą̧ab
Ciputat. Bandung : Zaman Wacana Mulia.

Nasution, Harun. 1995. "Tasawuf” dalam Budhy Munawar-Rahman (ed), Kontekstualisasi Doktrin Islam dalam Sejarah. Jakarta : Paramadina.

Nasr, Sayyid Hussein., 1969. Three Muslim Sages ; Avecina, Subrawardi, and 'Arabi, Canbridge : Harvard University Press.

1981. Knowledge and The Sacred, Edinburgh : Edinburgh University Press.

1993. Menjelajah Dunia Modrn; bimbingan Untuk Kaum Muda Muslim. Bandung : Mizan.

1991. Tasawnf

Dulu dan Sekarang, Jakarta : Pustaka Firdaus.

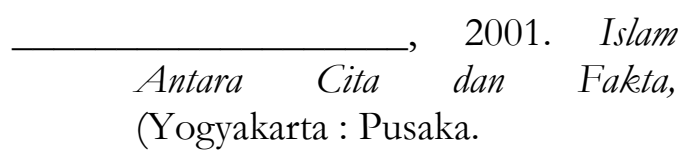

Purwantoro, dkk. 1991. Seluk Beluk Filsafat Islam, Bandung : Remaja Rosdakarya.

Pannikar, Raimundo, 1979, Myth, Faith, and Hermeneutics, New York : Paulist Press

Rahman, Fazlur. 1984. Islam, Bandung : Pustaka

Rahmat, Jalaludin, 2006., Islam dan Pluralisme ; Akblaq al-Qur'an Menyikapi Perbedaan, Jakarta : Serambi, 2006 
Rasyidi, HM. 1996. Empat Kuliah Agam Islam pada Perguruan Tinggi, Jakarta : Bulan Bintang.

Rahardjo, Dawam. 1996. "Mitos dalam Agama dan Kebudayaan" dalam Muhammad Wahyuni Nafis (ed), Rekontruksi dan Renungan Religius Islam, Jakarta : Paramadina

Ridla, Rasyid., 1980, Tafsir al-Manar, I, Beirut, Dar al-Makrifah,

Sirry, Mun'im A. (ed), 2004. Figh Lintas Agama ; Membangun Masyarakat Inklusif-Pluralis. Jakarta : Paramadina.

Sholihodin., Machfud. 1986 Pengantar Psikologi Umum, Surabaya : Sinar Wijaya.

Scimmel., Annimarie. 2000. Dimensi Mistik dalam Islam, (tri). Jakarta : Pustaka Firdaus.

1997. Rahasia Wajab Suci Ilabi ; Memabami Islam secara Fenomenologis, (tri), Bandung : Mizan.

Salim., Peter. dkk. 1996. The Contemporary Engglish-Indonesian Dictionary. Jakarta : Modern Inglish press.

Smith., D.E.. 1985, Agama dan Modernisasi Politik, Jakarta : Rajawali Press.

Salthout, M. 1994, Aqidab dan Syariat Islam, Jakarta : Bumi Aksara.

Surakhmad, Winarno, 1989. Pengantar Penelitian Ilmiah ; Dasar, Metode, dan Teknik, Bandung : Tarsito.
Saleh, Abdur Rahman, 1973. Didaktik Pendidikan Agama, Jakarta : Bulan Bintang.

Shihab, M. Quraisy, 2000. Tafsir alMishbah ; Pesan, Kesan dan Keserasian al-Qur'an, vol. I. Jakarta : Lentera Hati.

1999. Lentera Hati, Bandung : Mizan.

1998. Membumikan al-Qur'an ; Fungsi dan Peran Wabyu dalam Kebidupan Masyarakat, Bandung : Mizan.

Soedjatmoko, 1984, Etika Pembebasan; Pilihan Karangan tentang Agama, Kebudayaan, Sejarah, dan Ilmu Pengetahuan, Jakarta : LP3S

Titus, Horald H. 1984. Persoalan-Persoalan Filsafat, (tri) Jakarta : Bulan Bintang,

Thabathabai, 1973, Al-Mizan fi Tafsir alQur'an, Qum, al-HauzahalIlmiyah,

Usman, Fathimah. 2002. Wabdat alAdyan ; Dialog Pluralisme Agama. Yogyakarta : LKis.

Wijaya, Aden. 1997. "Pendidikan Islam dalam Pluralisme Agama" Dalam Pendidikan Islam dalam Peradapan Industrial. Yogyakarta : Aditya Media.

Wan Daud., Wan Mohamad Nor. 2003. Filsafat dan Praktik Pendidikan Islam Syed M. Naquib al-Attas, (trj). Bandung : Mizan.

Yasin., Sulchan, 1997. Kamus Lengkap Babasa Indonesia, Surabaya Penerbit Amanah. 